\title{
Study of the Interaction of Trimethyltin(IV) Chloride with N,N,N',N'-tetraethylethylenedimanine in Reference to Marine Environmental Pollution
}

\author{
E.M.Shoukry (Corresponding author) \\ Department of Chemistry, Faculty of Science, Al-Azhar University (Egypt)
}

$\&$

Taif University (Kingdom of Saudi Arabia)

Tel: 2-010-183-4458 fax: 2-35728843 E-mail: Eman_shoukry2002@hotmail.com

M. F. Amin

Department of Chemistry, Faculty of Science, Al-Azhar University, Egypt

Received: December 15, 2010

Accepted: February 13, 2011

doi:10.5539/mas.v5n2p71

\begin{abstract}
The interaction of trimethyltin(IV) with N,N,N',N'-tetraethylethylenediamine (Et ${ }_{4}$ en) was investigated potentiometrically. The hydrolysis constants of trimethyltin(IV) species and formation constants of the amine complexes are determined. The formation constant of the complex is high, which may suggest to use $\mathrm{Et}_{4} \mathrm{en}^{\mathrm{as}}$ an antidote for triorganotin(IV) poisoning, the main source of marine environmental pollution. The effect of solvent dielectric constant of the medium and temperature on the complex formation equilibria was investigated.
\end{abstract}

Keywords: Complex formation equilibria, trimethyltin(IV), Stability constant, Antidote, Speciation

\section{Introduction}

In the last two decades coordination compounds of organotin(IV) exhibit interesting antitumoural activity against several human cancer cell lives(Zhu et.al, 2004) and some of them are are extremely toxic to animals and humans (Cardiano et. al, 2008, Nolan et. al, 2005). The deleterious effect of trialkyltin(IV) derivatives is due to the inhibition of mitochondrial oxidative phosphorylation (Aldridge, 1976) and the ability to bind certain proteins (Elliott et. al, 1979). The toxicity of tetra-alkyltins also appears to be due trialkyltin(IV) species which are produced as a result of dealkylation in vivo. For these reasons, significant attention is paid to environmental pollution by alkyltin compounds and to their presence in food. Consequently there is a need to study their complex formation equilibria with a hope to find an antitode for it. With this in mind and in conjunction with our previous studies (Shoukry, 2002; Shoukry et.al, 1995; Shoukry et.al. 2000; Shoukry et.al. 1995; Shoukry et.al 1986), on metal complexes of biological significance, the present paper includes the results of the study of trimethyltin(IV) complexes with N,N,N',N'-tetraethylethylenediamine. The complex formation equilibria is investigated with the hope that such type of coordinating ligand might possess favorable properties, possibly as carries in body fluids.

\section{Experimental details}

\subsection{Materials and reagents}

Trimethyltin(IV) chloride (TMA) were supplied by Merk Chem. Co. N,N,N',N'-tetraethylethylenediamine $\left(\mathrm{Et}_{4} \mathrm{en}\right)$ was provided by Sigma Chem. Co. Sodium hydroxide stock solutions were prepared by diluting the content of BDH concentrated volumetric solution vials. These solutions were systematically checked by titration against potassium hydrogen phthalate. The amine solutions were prepared in the diprotonated form by dissolution in two equivalents of nitric acid solution.

\subsection{Equipments and Measuring Techniques}

Potentiometric titrations were performed with a Metrohm 686 titroprocessor. The titroprocessor and electrode were calibrated with standard buffer solutions( Bates, 1975), potassium hydrogen phthalate (pH 4.008) and a mixture of $\mathrm{KH}_{2} \mathrm{PO}_{4}$ and $\mathrm{Na}_{2} \mathrm{HPO}_{4}(\mathrm{pH} 6.865)$ at $25^{\circ} \mathrm{C}$. 
The protonation constants of the amine and the hydrolysis constants of trimethyltin(IV) ion were determined by titrating $40 \mathrm{ml}$ of the protonated amines $(1.25 \mathrm{mM})$ or the organotin(IV) $(1.25 \mathrm{mM})$ solutions in $25 \%$ dioxane-water system. The stability constants of the organotin(IV) complexes were determined by titrating $40 \mathrm{ml}$ of organotin(IV) $(1.25 \mathrm{mM})$ and the amine with concentration of $1.25 \mathrm{mM}$. All solutions were adjusted to $0.1 \mathrm{M}$ strength by addition of $\mathrm{NaNO}_{3}$, and were titrated against standard $0.05 \mathrm{M} \mathrm{NaOH}$.

The equilibrium constants were evaluated from titration data, defined by Eqns. (1) and (2)

$$
\begin{aligned}
& 1(\mathrm{M})+\mathrm{p}(\mathrm{L})+\mathrm{q}(\mathrm{H})=(\mathrm{M})_{1}(\mathrm{~L})_{\mathrm{p}}(\mathrm{H})_{\mathrm{q}} \\
& \beta_{\text {lpqr }}=\frac{\left[(\mathrm{M})_{1}(\mathrm{~L})_{\mathrm{p}}(\mathrm{H})_{\mathrm{q}}\right]}{[\mathrm{M}]^{1}[\mathrm{~L}]^{\mathrm{p}}[\mathrm{H}]^{\mathrm{q}}}
\end{aligned}
$$

Where, M, L, and H represent organotin(IV), amine and proton respectively. The calculations were performed using the computer program(Gans et.al, 1976) MINIQUA-75. The stoichiometries and stability constants of the complexes formed were determined by trying various possible composition models. The model selected gave the best statistical fit and was chemically constituent with the titration data without giving any systematic drift in the magnitude of various residuals, as described elsewhere (Gans et.al, 1976) .

The fitted model was tested by comparing the experimental titration data points and the theoretical curve calculated from the values of acid dissociation constants of the amine and formation constants of the corresponding complexes. Tables (1and 3) list the formation constants together with their standard deviations and sum of square of residuals as obtained from the program MINIQUAD-75. The concentration distribution diagrams were obtained using the program SPECIES (Pettit).

\section{Results and Discussion}

The acid-dissociation constants of the amine in the protonated form were determined under the same experimental conditions of ionic strength $(0.1 \mathrm{M})$ and temperature $\left(25^{\circ} \mathrm{C}\right)$ used for the study of trimethyltin(IV) complex equilibria.

\subsection{Hydrolysis of trimethyltin(IV)}

The hydrolysis of trimethyltin(IV) (TMT) ion was previously investigated (Takahashi et.al.,1997, Hynes et. al., 1987) and the results were contradictory. The acid-base chemistry of trimethyltin(IV) has been investigated. The fitted model according to the aforementioned method of calculation was found to be consistent with the following acid-base equilibria, Scheme (1).

The hydrolysed species 10-1, 10-2 and 20-1 were consistent with the model proposed by Takahashi et al. (Takahashi et. al., 1997). Considering the species 20-2 and 20-3, Scheme (1), were found to improve the data fitting. The formation of the dimeric species through $\mathrm{OH}^{-}$group was previously established by Extended X-ray Absorption Fine Structure (EXAFS) method (Takahashi et. al., 1997). The concentration distribution diagram for the hydrolysis of TMT is shown in Fig. (1).

\subsection{Organotin(IV) complexes with Et $t_{4}$ :n:}

The acid-base equilibria of the $\mathrm{Et}_{4} \mathrm{en}$, abbreviated as $\mathrm{L}$, was investigated under the experimental conditions applied for the study of the stability constants of the organotin(IV) complexes. The titration data reveals the formation of simple $\mathrm{L}, \mathrm{HL}^{+}$and $\mathrm{H}_{2} \mathrm{~L}^{2+}$ complex species, where $\mathrm{L}$ represents $\mathrm{Et}_{4} \mathrm{en}$ in the neutral form. The calculated overall protonation constants in aqueous solution at $25^{\circ} \mathrm{C}$, in dioxane-water solution of various proportion and at different temperature are given in (Tables 1,3 ). The $\mathrm{pK}_{\mathrm{a}}$ values of the protonated $\mathrm{Et}_{4} \mathrm{en}$ in dioxane-water solutions are higher than those reported in water. This may be due the increased basicity of the ligand donor groups when one goes from water to dioxane solutions.

A comparison of the potentiometric titration curves of protonated $\mathrm{Et}_{4} \mathrm{en}$ in the presence and absence of TMT shows that the complex titration curve is located at significantly lower $\mathrm{pH}$ value than that of the ligand. This corresponds to the formation of a complex species through release of a hydrogen ion. The formation equilibria were characterized by fitting their potentiometric data to various models; the best result were obtained for complexes with stoichiometric coefficients (110), (111) and (11-1). This model was tested by comparing the experimental titration data with theoretical curve calculated from the $\mathrm{pK}_{\mathrm{a}}$ of the ligand and the stability constant of the formed complexes. A good agreement between the experimental and theoretical data, Figs. (2), proved the validity of the model proposed.

The concentration distribution diagram of $\mathrm{Et}_{4}$ en complex with trimethyltin(IV) ion gives an interesting 
information regarding the behavior of these organometallic compounds in biological systems. The distribution diagram is depicted in Fig. 3. It is interesting to note that in the physiological $\mathrm{pH}$ range the complex formation is quite feasible.

\subsection{Effect of Temperature}

The thermodynamic parameters $\Delta \mathrm{H}^{\circ}$ and $\Delta \mathrm{S}^{\circ}$ associated with the protonation of $\mathrm{N}, \mathrm{N}, \mathrm{N}^{\prime}, \mathrm{N}^{\prime}$-tetraethylethylendiamine $\left(\mathrm{Et}_{4} \mathrm{en}\right)$, hydrolysis of trimethyltin(IV) ion and its complex formation with $\mathrm{Et}_{4}$ en were calculated from the temperature dependence of the data in Table (1). $\Delta \mathrm{H}^{\circ}$ and $\Delta \mathrm{S}^{\mathrm{o}}$ were obtained by linear least square fit of $\ln \mathrm{K} v s .1 / \mathrm{T}\left(\ln \mathrm{K}=-\Delta \mathrm{H}^{\mathrm{o}} / \mathrm{RT}+\Delta \mathrm{S}^{\mathrm{o}} / \mathrm{R}\right)$ leading to an intercept $\quad \Delta \mathrm{S}^{\mathrm{o}} / \mathrm{R}$ and a slope $-\Delta \mathrm{H}^{\mathrm{o}} / \mathrm{R}$, where $\mathrm{K}$ is the equilibrium constant and $\mathrm{R}$ is the universal gas constant. These data can be employed to extrapolate the equilibrium constants to other temperatures. The main conclusions from the data can be summarized as follows:

a) The formation constant for the hydroxyl complexes of trimethyltin(IV), оH $_{\text {can }}$ be calculated as:

$$
\log \left(\beta_{\mathrm{OH}}\right)_{10-1}=\log \mathrm{K}_{\mathrm{w}}+\log \beta 10-1
$$

The hydrolysis reactions (1-5) of TMT in Table (2) are exothermic, i. e. the hydrolysis are favored. The $\Delta \mathrm{H}^{\circ}$ values in Table (2) can be considered as the net summation of two opposing effects, namely the exothermic hydrolysis reaction and the endothermic liberation of ordered water of hydration. Reaction (3) leading to the formation of 20-1 species is endothermic. It has the largest change in entropy $\left(\Delta \mathrm{S}^{\circ}=242.3 \mathrm{~J} \cdot \mathrm{K}^{-1} \cdot \mathrm{mol}^{-1}\right)$ due to the release of two ordered water molecules of hydration. This makes more negative the free energy change $\left(\Delta \mathrm{G}^{\circ}\right.$ $\left.=-65.6 \mathrm{~kJ} \cdot \mathrm{mol}^{-1}\right)$. Also, the formation of species 20-1, can be considered as a summation of reaction (1), the formation of species 10-1 and the dimerization reaction (6). Although, the dimerization reaction (6) has a positive $\Delta \mathrm{H}^{\circ}$, it has a large entropy change $114.0 \mathrm{~J}^{-1} \cdot \mathrm{mol}^{-1}$ due to loss of ordered water of hydration, so the net contribution to $\Delta \mathrm{G}^{\circ}$ is negative $\left(\Delta \mathrm{G}^{\circ}=-19.8 \mathrm{~kJ}^{\circ} \mathrm{mol}^{-1}\right)$. The formation of $10-1$, reaction (1), and 20-2, reaction (4), both have similar $\Delta \mathrm{G}^{\circ}$ and large $\Delta \mathrm{S}^{\circ}$. The formation of 10-2, reaction (2), and 20-3, reaction (5), both have comparable values of $\Delta \mathrm{H}^{\circ}, \Delta \mathrm{S}^{\circ}$ and $\Delta \mathrm{G}^{\circ}$. Although they have more negative $\Delta \mathrm{H}^{\circ}$ values, they are the least favored species $\Delta \mathrm{G}^{\circ} \sim-20 \mathrm{~kJ}$. mol ${ }^{-1}$. This can be due to the longer bond length (Takahashi et. al., 1997) of the water molecules in the species 10-1 and 20-2. So, the loss of water molecules is not accompanied by a large disorder and the formation of species 10-2 and 20-3 have net negative $\Delta \mathrm{S}^{\circ}$ of -18.2 and $-13.5 \mathrm{~J}^{-1} \mathrm{~K}^{-1}$. $\mathrm{mol}^{-1}$, respectively.

b) The protonation reactions (7) and (8) of $\mathrm{Et}_{4} \mathrm{en}$ are exothermic and of comparable $\Delta \mathrm{H}^{\circ}$ value. Three factors affects the protonation reactions: (i). The neutralization reaction, which an exothermic process. (ii). Desolvation of ions, which is an endothermic process. (iii). The change of the configuration and the arrangements of the hydrogen bonds around the free and the protonated ligands.

c) The complexation reaction $(10,11)$ of $\mathrm{TMT}_{\text {with }} \mathrm{Et}_{4} \mathrm{en}$ is exothermic, $\Delta \mathrm{H}^{\circ}$ values are negative -53.63 and $-30.25 \mathrm{~kJ} . \mathrm{mol}^{-1}$.

\subsection{Effect of solvent}

It is well established that the "effective" or "equivalent solution" dielectric constants in proteins (Kramer-Schnabel et. al., 1991; Rees, 1980) or active site cavities of enzymes(Rogers et. al., 1985) are smaller compared to that in bulk water. Estimates for the dielectric constants in such locations range from 30 to 70(Kramer-Schnabel et. al., 1991; Rees, 1980; Rogers et.al., 1985; Sigel et. al., 1985). Hence by using aqueous solutions containing $\approx 10-50 \%$ dioxane, one may expect to simulate to some degree the situation in active site cavities (Akerlof et.al., 1953), hence to extrapolate the data to physiological conditions. Careful examination of the medium effect on the equilibrium constants reveal the following features:

a) $\mathrm{pK}_{\mathrm{a}}$ of the protonated $\mathrm{Et}_{4} \mathrm{en}$ decreases linearly with increasing the percentage of organic solvent in the medium. This may be explained by better solvation of the neutral $\mathrm{Et}_{4} \mathrm{en}$ by dioxane.

b) The hydrated trimethyltin(IV) is subjected to hydrolysis by deprotonation as shown in Scheme (1). The deprotonation constants are increased with increasing dioxane proportion of the solvent. This may be correlated with the ability of a solvent of relatively low dielectric constant to increase the electrostatic attraction between the ionized proton and the hydrolysed species of trimethyltin(IV) ion.

c) The formation constants for trimethyltin(IV) complexes with $\mathrm{Et}_{4} \mathrm{en}$ decrease upon addition of dioxane to an aqueous solution of the corresponding species. This can be explained by better solvation of virtually hydrophobic species $\mathrm{CH}_{3} \mathrm{Sn}^{+} / \mathrm{CH}_{3} \mathrm{SnCl}$ by dioxane resulting in lowering the complex stability. This behaviour is in agreement with that proposed for alkyltin(IV) complexes with D-glucosamine(Shoukry et. al., 1997). 


\section{Conclusion}

The present report includes the results of the study of the interaction of trimethyltin(IV) compounds with $\mathrm{Et}_{4} \mathrm{en}$. The formation constants of the corresponding complexes were determined and the concentration distribution diagram was evaluated. The high stability constant of the complex may suggest to use $\mathrm{Et}_{4} \mathrm{en}$ as an antidote for the triorganotin(IV) poisoning, which is one of the major contaminant in the marine environment

\section{Acknowledgement}

The author in indebted to the Department of Chemistry, Faculty of Science, Taif University, Saudi Arabia, for the financial support for the present project.

\section{References}

Akerlof G and Short O A. (1953). J. Am. Chem. Soc., 75, 6357.

Aldridge W. (1976). Adv. Chem. Ser., 186, 157.

Bates R G. (1975). Determination of pH-Theory and Practice, 2nd edn. Wiley, New York.

Cardiano P, De Stefano C, Giuffre O and Sammatano S. (2008). Biophysical Chem., 133, 19.

Elliott B, Aldridge W and Bridges J. (1979). Biochem. J. 177, 461.

Gans P, Sabatini A and Vacca A. (1976). Inorg. Chim. Acta 18, 237.

Gielen M. (2002). Appl. Organomet. Chem. 16, 481.

Hynes M J and O'Dowd J. (1987). J. Chem. Soc. Dalton Trans., 563.

Kramer-Schnabel U and Linder P W. (1991). Inorg. Chem., 30, 1248.

Nolan D, Loan D, Tolosa I, de Mora S. (2005). Appl. Organometal. Chem., 19, 811.

Pettit L (University of Leeds), Personal Communication.

Rees D O. (1980). J. Mol. Biol., 141, 323.

Rogers N K, Roore G R and Strenberg M J E. (1985). J. Mol. Biol., 182, 613.

Sherman S E and Lippard S J. (1987). Chem. Rev., 87, 1153.

Shoukry E M. (2002). Acta Pharm., 52, 189.

Shoukry E M, Khalil M M, Elghandour A H H and Shoukry M M. (1995). Monatsh. Chem., 126, 241.

Shoukry E M, Shoukry M M, Mahgoub A E and Galal H M. (2000). Ann. Chim. (Rome), 90, 593.

Shoukry M M, Shoukry E M and El-Medani S M. (1995). Monatsh. Chem., 126, 905.

Shoukry M M , Khater M M and Shoukry E M. (1986). Indian J. Chem., 25A, 488.

Shoukry M M and El-Medani S M. (1997). Collect. Czech. Chem. Commun., 62, 1023.

Sigel H, Martin R B, Tribolet R, Haring U K and Malini-Balakrishran R. (1985). Eur. J. Biochem., 152, 187.

Takahashi A, Natsume T, Koshino N, Funahashe S, Inada Y and Takagi H. (1997). Can. J. Chem., 75 , 1084.

Zhu S, Matilla A, Tercero J M, Vijayaragavan V and Walmsley J A. (2004). Inorg. Chim. Acta, 357, 411. 
Table 1. Formation Constants of trimethyltin(IV) (TMT) Complexes in Water at Different Temperature.

\begin{tabular}{|c|c|c|c|c|c|c|}
\hline System $^{\mathrm{a}}$ & Temp. $\left({ }^{\circ} \mathrm{C}\right)$ & 1 & $\mathrm{p}$ & $\mathrm{q}^{\mathrm{b}}$ & $\log \beta^{c}$ & $\mathrm{~S}^{\mathrm{d}}$ \\
\hline \multirow[t]{5}{*}{ TMT } & 15 & 1 & 0 & -1 & $-6.14(0.01)$ & $3.3 \mathrm{E}-8$ \\
\hline & & 1 & 0 & -2 & $-16.84(0.04)$ & \\
\hline & & 2 & 0 & -1 & $-2.74(0.02)$ & \\
\hline & & 2 & 0 & -2 & $-9.07(0.01)$ & \\
\hline & & 2 & 0 & -3 & $-19.40(0.04)$ & \\
\hline \multirow[t]{5}{*}{$\mathrm{TMT}-\mathrm{Et}_{4} \mathrm{en}$} & & 0 & 1 & 1 & $9.94(0.01)$ & $1.5 \mathrm{E}-8$ \\
\hline & & 0 & 1 & 2 & $16.80(0.01)$ & \\
\hline & & 1 & 1 & 0 & $6.81(0.00)$ & $5.4 \mathrm{E}-10$ \\
\hline & & 1 & 1 & 1 & $13.26(0.01)$ & \\
\hline & & 1 & 1 & -1 & $-3.20(0.02)$ & \\
\hline \multirow[t]{5}{*}{ TMT } & 20 & 1 & 0 & -1 & $-6.01(0.01)$ & $3.2 \mathrm{E}-8$ \\
\hline & & 1 & 0 & -2 & $-16.61(0.04)$ & \\
\hline & & 2 & 0 & -1 & $-2.62(0.02)$ & \\
\hline & & 2 & 0 & -2 & $-8.83(0.01)$ & \\
\hline & & 2 & 0 & -3 & $-19.04(0.04)$ & \\
\hline \multirow[t]{5}{*}{$\mathrm{TMT} \mathrm{Et}_{4} \mathrm{en}$} & & 0 & 1 & 1 & $9.81(0.01)$ & $1.4 \mathrm{E}-8$ \\
\hline & & 0 & 1 & 2 & $16.54(0.01)$ & \\
\hline & & 1 & 1 & 0 & $6.68(0.00)$ & $3.9 \mathrm{E}-10$ \\
\hline & & 1 & 1 & 1 & $13.08(0.01)$ & \\
\hline & & 1 & 1 & -1 & $-3.48(0.04)$ & \\
\hline \multirow[t]{5}{*}{ TMT } & 25 & 1 & 0 & -1 & $-5.90(0.02)$ & $3.8 \mathrm{E}-8$ \\
\hline & & 1 & 0 & -2 & $-16.40(0.03)$ & \\
\hline & & 2 & 0 & -1 & $-2.44(0.02)$ & \\
\hline & & 2 & 0 & -2 & $-8.56(0.04)$ & \\
\hline & & 2 & 0 & -3 & $-18.70(0.05)$ & \\
\hline \multirow[t]{5}{*}{$\mathrm{TMT} \mathrm{Et}_{4} \mathrm{en}$} & & 0 & 1 & 1 & $9.65(0.01)$ & $3.4 \mathrm{E}-8$ \\
\hline & & 0 & 1 & 2 & $16.22(0.02)$ & \\
\hline & & 1 & 1 & 0 & $6.52(0.00)$ & $9.7 \mathrm{E}-10$ \\
\hline & & 1 & 1 & 1 & $12.80(0.01)$ & \\
\hline & & 1 & 1 & -1 & $-3.21(0.05)$ & \\
\hline \multirow[t]{5}{*}{ TMT } & 30 & 1 & 0 & -1 & $-5.78(0.02)$ & 7.7E-8 \\
\hline & & 1 & 0 & -2 & $-16.22(0.04)$ & \\
\hline & & 2 & 0 & -1 & $-2.27(0.03)$ & \\
\hline & & 2 & 0 & -2 & $-8.28(0.02)$ & \\
\hline & & 2 & 0 & -3 & $-18.37(0.08)$ & \\
\hline \multirow[t]{8}{*}{$\mathrm{TMT} \mathrm{Et}_{4} \mathrm{en}$} & & 0 & 1 & 1 & $9.51(0.01)$ & $9.3 \mathrm{E}-9$ \\
\hline & & 0 & 1 & 2 & $15.94(0.01)$ & \\
\hline & & 1 & 1 & 0 & $6.36(0.01)$ & $2.3 \mathrm{E}-9$ \\
\hline & & 1 & 1 & 1 & $12.53(0.02)$ & \\
\hline & & 1 & 1 & -1 & $-2.81(0.03)$ & \\
\hline & & 1 & 1 & 0 & $6.18(0.00)$ & $1.3 \mathrm{E}-10$ \\
\hline & & 1 & 1 & 1 & $12.30(0.01)$ & \\
\hline & & 1 & 1 & -1 & $-2.58(0.04)$ & \\
\hline
\end{tabular}

${ }^{\mathrm{a}} \mathrm{l}, \mathrm{p}$ and $\mathrm{q}$ are the stoichiometric coefficient corresponding to organotin(IV), $\mathrm{Et}_{4} \mathrm{en}$ and $\mathrm{H}^{+}$, respectively; ${ }^{\mathrm{c}}$ Standard deviations are given in parentheses; ${ }^{\mathrm{d}}$ Sum of square of residuals. 
Table 2. Thermodynamic parameters for the equilibria of trimethyltin(IV) complexes. ${ }^{\mathrm{a}}$

\begin{tabular}{|c|c|c|c|}
\hline Equilibrium $^{\text {b }}$ & $\begin{array}{l}\Delta \mathbf{H}^{\circ} \\
\mathbf{k J m o l}^{-1}\end{array}$ & $\begin{array}{c}\Delta \mathrm{S}^{\circ} \\
\mathrm{JK}^{-1} \mathbf{m o l}^{-1} \\
\end{array}$ & $\begin{array}{l}\Delta \mathbf{G}^{\circ} \\
\mathbf{k J m o l}^{-1}\end{array}$ \\
\hline $\begin{array}{l}\text { TMT } \\
\begin{array}{l}\text { 1) } \mathrm{M}\left(\mathrm{H}_{2} \mathrm{O}\right)_{2}{ }^{+}+\mathrm{OH}^{-} \rightleftharpoons \\
\text { 2) } \mathrm{M}\left(\mathrm{H}_{2} \mathrm{O}\right)(\mathrm{OH})+\mathrm{OH}^{-}\end{array} \begin{array}{c}\mathrm{M}\left(\mathrm{H}_{2} \mathrm{O}\right)(\mathrm{OH})+\mathrm{H}_{2} \mathrm{O} \\
\mathrm{M}(\mathrm{OH})_{2}^{-}+\mathrm{H}_{2} \mathrm{O}\end{array}\end{array}$ & $-7.63(0.12)$ & $128.3(1.1)$ & $-45.9(1.2)$ \\
\hline $\begin{array}{l}\text { 3) } 2 \mathrm{M}\left(\mathrm{H}_{2} \mathrm{O}\right)_{2}^{+}+\mathrm{OH}^{-} \rightleftharpoons \\
2 \mathrm{H}_{2} \mathrm{O}\end{array}$ & $-24.8(0.3)$ & $-18.2(0.4)$ & $-19.4(0.5)$ \\
\hline $\begin{array}{l}\text { 4) } \mathrm{M}_{2}\left(\mathrm{H}_{2} \mathrm{O}\right)_{2}(\mathrm{OH})^{+}+\mathrm{OH}^{-} \rightleftharpoons \\
+\mathrm{H}_{2} \mathrm{O}\end{array}$ & $6.60(0.13)$ & $242.3(1.2)$ & $-65.6(1.4)$ \\
\hline $\begin{array}{l}\text { 5) } \mathrm{M}_{2}\left(\mathrm{H}_{2} \mathrm{O}\right)(\mathrm{OH})_{2}+\mathrm{OH}^{-} \rightleftharpoons \mathrm{M}_{2}(\mathrm{OH})_{3}^{-}+\mathrm{H}_{2} \mathrm{O} \\
\text { 6) } \quad \mathrm{M}\left(\mathrm{H}_{2} \mathrm{O}\right)_{2}^{+}+\mathrm{M}\left(\mathrm{H}_{2} \mathrm{O}\right)(\mathrm{OH})\end{array}$ & $-14.7(0.2)$ & $100.2(1.0)$ & $-44.6(0.9)$ \\
\hline $\mathrm{M}_{2}\left(\mathrm{H}_{2} \mathrm{O}\right)_{2}(\mathrm{OH})+\mathrm{H}_{2} \mathrm{O}$ & $-25.5(0.4)$ & $-13.5(0.5)$ & $-21.5(0.7)$ \\
\hline & $14.2(0.2)$ & $114.0(1.2)$ & $-19.8(0.4)$ \\
\hline $\mathbf{E t}_{4} \mathbf{e n}$ & & & \\
\hline 7) $\mathrm{L}+\mathrm{H}^{+} \longleftarrow \mathrm{LH}^{+}$ & -49.60 & -40.76 & -37.44 \\
\hline 8) $\mathrm{LH}^{+}+\mathrm{H}^{+} \rightleftharpoons \mathrm{LH}_{2}^{2+}$ & -45.78 & 31.98 & -55.31 \\
\hline 9) $\mathrm{L}+2 \mathrm{H}^{+} \rightleftharpoons \mathrm{LH}_{2}^{2+}$ & -95.38 & -8.74 & -92.75 \\
\hline
\end{tabular}

\section{TMT-Et 4 en}

10) $\mathrm{M}(\mathrm{Cl})+\mathrm{L} \rightleftharpoons \mathrm{ML}(\mathrm{Cl})$

$-53.63$

$-55.39$

$-37.12$

11) $\mathrm{M}(\mathrm{Cl})+\mathrm{LH}^{+} \rightleftharpoons \operatorname{MLH}(\mathrm{Cl})^{+}$

$-30.25$

18.76

$-35.84$

12) $\mathrm{MLCl} \rightleftharpoons \mathrm{MCl}\left(\mathrm{LH}_{-1}\right)+\mathrm{H}^{+}$

$-153.80$

$-331.08$

$-555.09$

\footnotetext{
${ }^{a}$ TMT or M denote trimethyltin(IV), $\mathrm{Et}_{4}$ en denote tetraethylethylenediamine; Standard deviations are given in parentheses. ${ }^{\mathrm{b}}$ Stepwise formation constants.
} 
Table 3. Formation Constants of Trimethyltin(IV) Complexes with $\mathrm{Et}_{4} \mathrm{en}$ in Dioxane-Water Solutions of Different Compositions.

\begin{tabular}{|c|c|c|c|c|c|c|}
\hline System & Dioxane \% & 1 & $\mathbf{P}$ & $\mathbf{q}^{\mathbf{a}}$ & $\log \beta^{b}$ & $\mathbf{S}^{\mathbf{c}}$ \\
\hline \multirow[t]{5}{*}{ TMT } & 12.5 & 1 & 0 & -1 & $-6.16(0.03)$ & $1.6 \mathrm{E}-7$ \\
\hline & & 1 & 0 & -2 & $-16.67(0.07)$ & \\
\hline & & 2 & 0 & -1 & $-2.45(0.08)$ & $5.1 \mathrm{E}-8$ \\
\hline & & 2 & 0 & -2 & $-9.12(0.06)$ & \\
\hline & & 2 & 0 & -3 & $-19.54(0.07)$ & \\
\hline \multirow[t]{5}{*}{$\mathrm{TMT} \mathrm{Et}_{4} \mathrm{en}$} & & 0 & 1 & 1 & $9.75(0.01)$ & $1.8 \mathrm{E}-8$ \\
\hline & & 0 & 1 & 2 & $16.40(0.02)$ & \\
\hline & & 1 & 1 & 0 & $6.33(0.00)$ & $5.3 \mathrm{E}-10$ \\
\hline & & 1 & 1 & 1 & $11.89(0.06)$ & \\
\hline & & 1 & 1 & -1 & $-2.52(0.07)$ & \\
\hline \multirow[t]{5}{*}{ TMT } & 25 & 1 & 0 & -1 & $-6.21(0.02)$ & $4.4 \mathrm{E}-8$ \\
\hline & & 1 & 0 & -2 & $-16.96(0.05)$ & \\
\hline & & 2 & 0 & -1 & $-2.73(0.02)$ & \\
\hline & & 2 & 0 & -2 & $-9.29(0.01)$ & \\
\hline & & 2 & 0 & -3 & $-19.94(0.03)$ & \\
\hline \multirow[t]{5}{*}{$\mathrm{TMT} \mathrm{Et}_{4} \mathrm{en}$} & & 0 & 1 & 1 & $9.57(0.01)$ & $2.8 \mathrm{E}-9$ \\
\hline & & 0 & 1 & 2 & 16.02(0.01) & \\
\hline & & 1 & 1 & 0 & $6.11(0.00)$ & $1.83 \mathrm{E}-9$ \\
\hline & & 1 & 1 & 1 & $11.79(0.03)$ & \\
\hline & & 1 & 1 & -1 & $-2.49(0.04)$ & \\
\hline \multirow[t]{5}{*}{ TMT } & 37.5 & 1 & 0 & -1 & $-6.39(0.02)$ & $6.1 \mathrm{E}-8$ \\
\hline & & 1 & 0 & -2 & $-17.29(0.06)$ & \\
\hline & & 2 & 0 & -1 & $-2.86(0.03)$ & \\
\hline & & 2 & 0 & -2 & $-9.62(0.02)$ & \\
\hline & & 2 & 0 & -3 & $-20.39(0.08)$ & \\
\hline \multirow{5}{*}{$\mathrm{TMT} \mathrm{Et}_{4} \mathrm{en}$} & & 0 & 1 & 1 & $9.38(0.01)$ & $1.1 \mathrm{E}-8$ \\
\hline & & 0 & 1 & 2 & $15.72(0.01)$ & \\
\hline & & 1 & 1 & 0 & $5.82(0.01)$ & $1.4 \mathrm{E}-8$ \\
\hline & & 1 & 1 & 1 & 11.71(0.09) & \\
\hline & & 1 & 1 & -1 & $-2.52(0.06)$ & \\
\hline \multirow[t]{10}{*}{ TMT } & 50 & 1 & 0 & -1 & $-6.54(0.03)$ & $3.8 \mathrm{E}-8$ \\
\hline & & 1 & 0 & -2 & $-17.60(0.05)$ & \\
\hline & & 2 & 0 & -1 & $-2.98(0.02)$ & \\
\hline & & 2 & 0 & -2 & $-9.90(0.01)$ & \\
\hline & & 2 & 0 & -3 & $-20.83(0.05)$ & \\
\hline & & 0 & 1 & 1 & $9.17(0.01)$ & $1.5 \mathrm{E}-8$ \\
\hline & & 0 & 1 & 2 & $15.30(0.01)$ & \\
\hline & & 1 & 1 & 0 & $5.50(0.01)$ & $3.7 \mathrm{E}-9$ \\
\hline & & 1 & 1 & 1 & $11.54(0.05)$ & \\
\hline & & 1 & 1 & -1 & $-2.51(0.03)$ & \\
\hline
\end{tabular}


TMT

62.5

$\begin{array}{ll}1 & 0 \\ 1 & 0 \\ 2 & 0 \\ 2 & 0 \\ 2 & 0\end{array}$

$\begin{array}{rrrrr}1 & 0 & -1 & -6.70(0.02) & 1.7 \mathrm{E}-7 \\ 1 & 0 & -2 & -17.87(0.07) & \\ 2 & 0 & -1 & -3.11(0.05) & \\ 2 & 0 & -2 & -10.15(0.04) & \\ 2 & 0 & -3 & -21.28(0.09) & \\ 0 & 1 & 1 & 9.04(0.01) & 1.1 \mathrm{E}-8 \\ 0 & 1 & 2 & 15.11(0.01) & \\ 1 & 1 & 0 & 5.20(0.01) & 1.5 \mathrm{E}-8 \\ 1 & 1 & 1 & 11.37(0.08) & \\ 1 & 1 & -1 & -2.51(0.03) & \end{array}$

TMT-Et $_{4}$ en

${ }^{\mathrm{a}} \mathrm{l}, \mathrm{p}$ and $\mathrm{q}$ are the stoichiometric coefficient corresponding to organotin(IV), $\mathrm{Et}_{4} \mathrm{en}$ and $\mathrm{H}^{+}$respectively;

${ }^{\mathrm{b}}$ Standard deviations are given in parentheses; ${ }^{\mathrm{c}} \mathrm{Sum}$ of square of residuals.<smiles></smiles>

(100)<smiles>[3H]C(C)(O)C(C)(C)O</smiles>

$\mathbf{p K}_{3} \| \begin{aligned} & -\mathrm{H}^{+} \\ & -\mathrm{H}_{2} \mathrm{O}\end{aligned}$<smiles>CC(C)([Si](C)(C)O)[Si](C)(C)O</smiles>

(20-1)<smiles></smiles>

(10-1)<smiles>C[Si](C)(O)O</smiles>

(10-2)<smiles>CC(C)(O)[Si](C)(C)O</smiles>

$(20-2)$<smiles>C[Si](C)(O)O[Si](C)(C)[Si](C)(C)O</smiles>

(20-3)

Scheme (1) The acid - base equlibria of trimethyltin(IV) species 


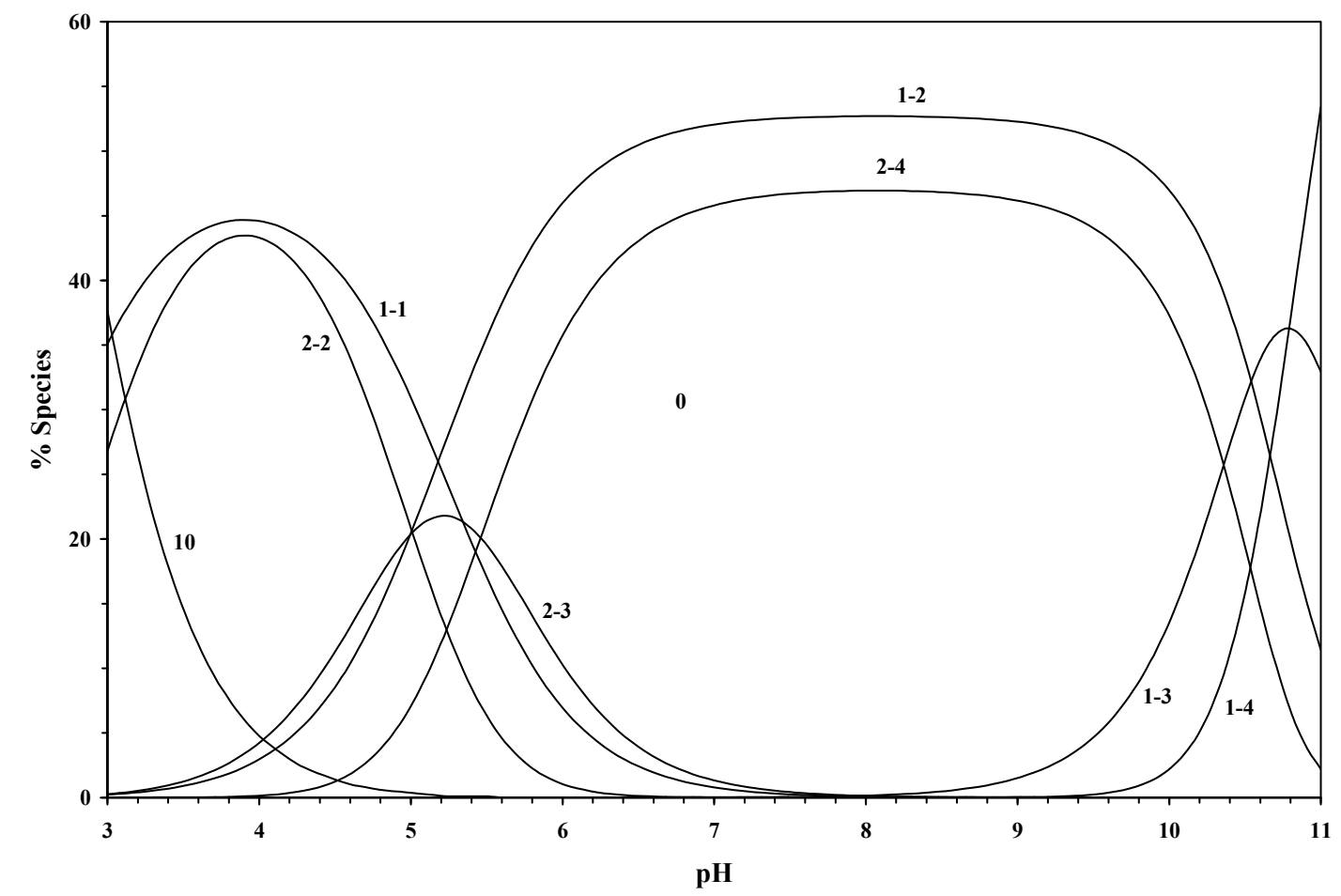

Figure 1. Concentration distribution of various species as a function of $\mathrm{pH}$ in the $\mathrm{Sn}\left(\mathrm{CH}_{3}\right)_{3}-\mathrm{OH}$ system. (at concentrations of $1.25 \mathrm{mmol} /$ liter for $\left(\mathrm{CH}_{3}\right)_{3} \mathrm{Sn}(\mathrm{IV})$ 


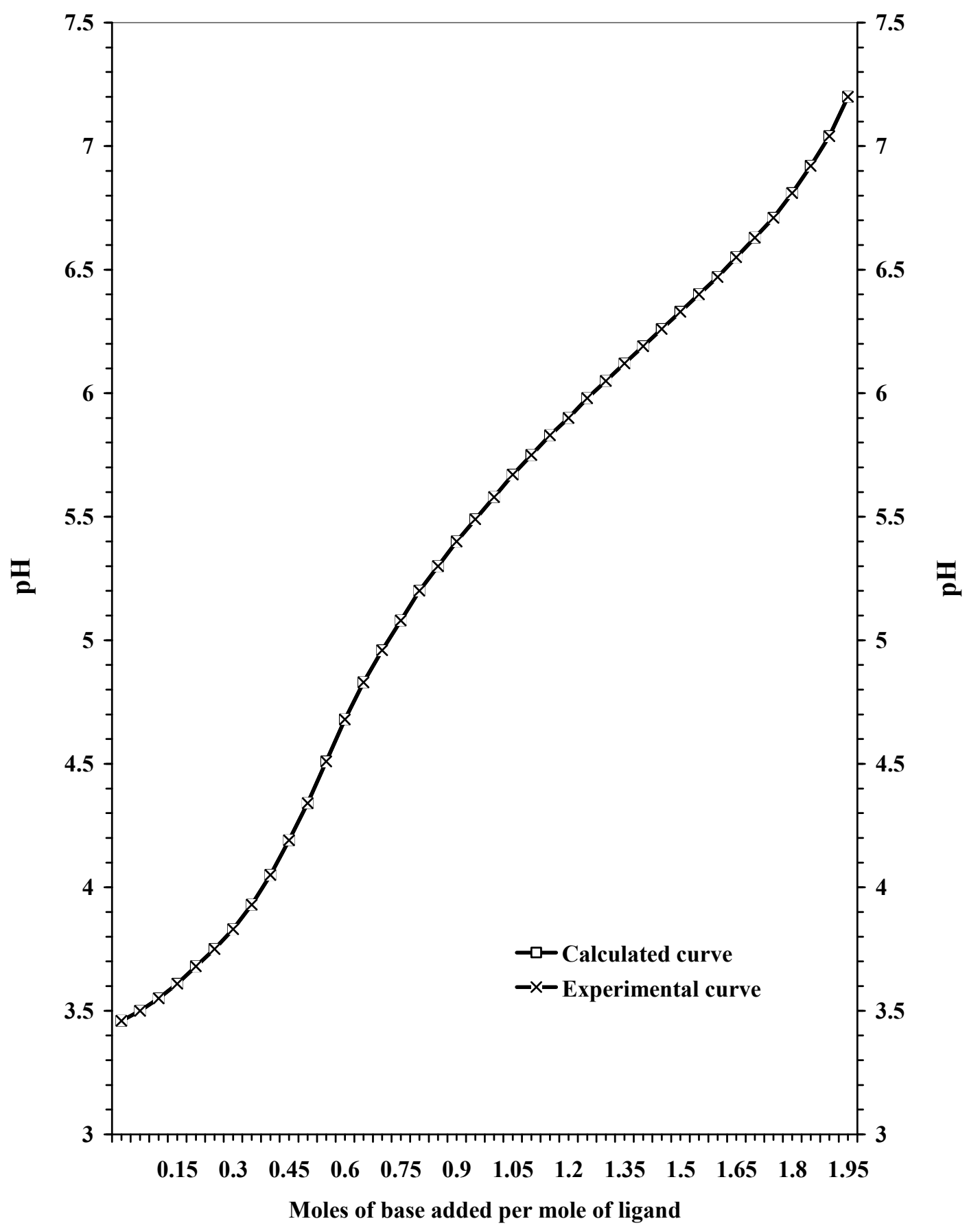

Figure 2. Potentiometric titration curve of the TMT-Et4en system 


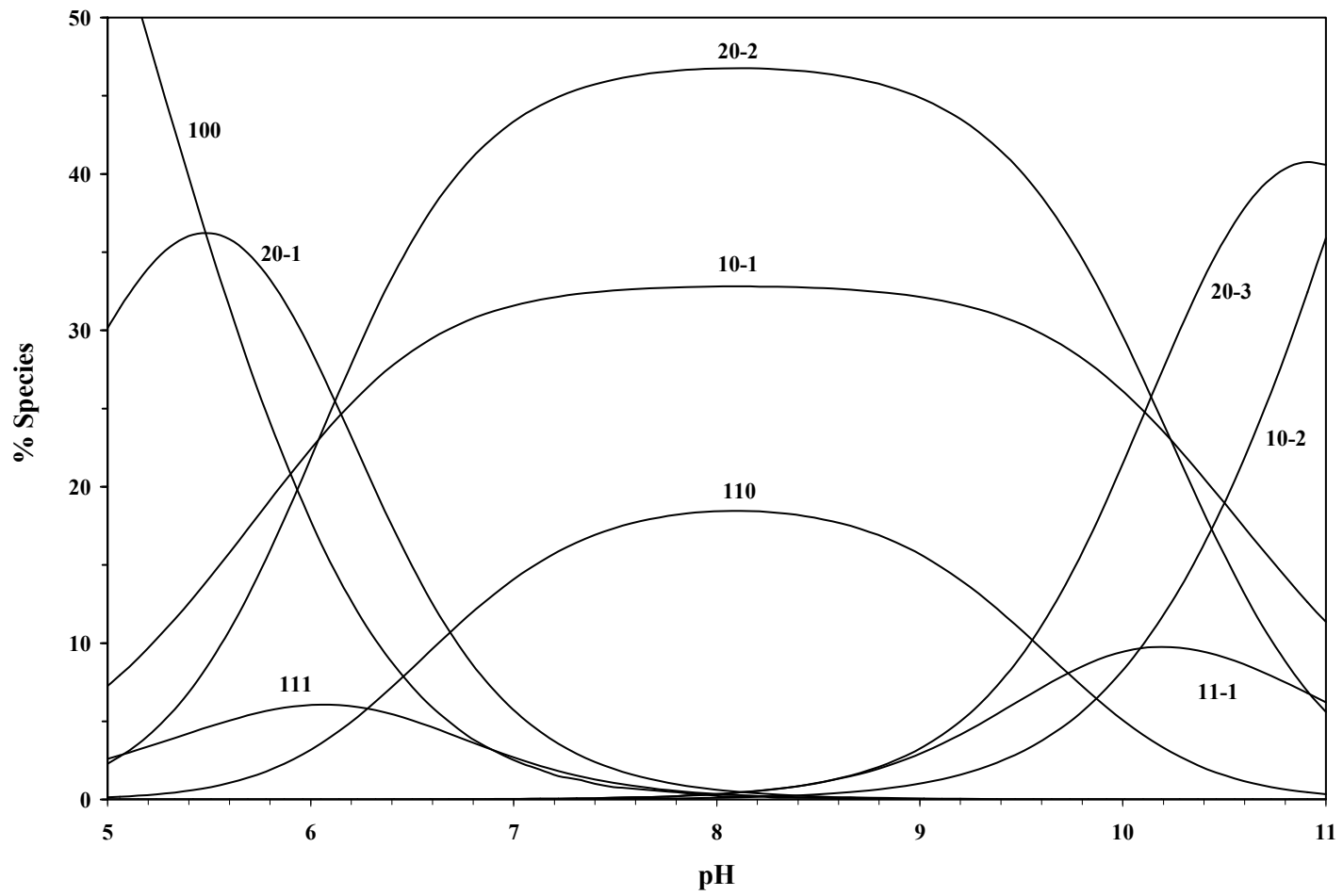

Figure 3. Concentration distribution of various species as a function of $\mathrm{pH}$ in the $\mathrm{TMT}^{-\mathrm{Et}_{4} \mathrm{en} \text { system }}$ 